九州大学学術情報リポジトリ

Kyushu University Institutional Repository

\title{
Radionuclides Removal from Aqueous Solutions: A Mini Review on Using Different Sorbents
}

Maamoun, Ibrahim

Water and Environmental Engineering Laboratory, Interdisciplinary Graduate School of Engineering Sciences, Kyushu University

Eljamal, Ramadan

Water and Environmental Engineering Laboratory, Interdisciplinary Graduate School of Engineering Sciences, Kyushu University

Falyouna, Omar

Water and Environmental Engineering Laboratory, Interdisciplinary Graduate School of Engineering Sciences, Kyushu University

Bensaida, Khaoula

Water and Environmental Engineering Laboratory, Interdisciplinary Graduate School of Engineering Sciences, Kyushu University

他

https://doi.org/10.5109/4738585

出版情報: Proceedings of International Exchange and Innovation Conference on Engineering \& Sciences (IEICES). 7，pp.170-177，2021-10-21. 九州大学大学院総合理工学府 バージョン :

権利関係 : 


\title{
Radionuclides Removal from Aqueous Solutions: A Mini Review on Using Different Sorbents
}

\author{
Ibrahim Maamoun $^{1}$, Ramadan Eljamal ${ }^{1}$, Omar Falyouna ${ }^{1}$, Khaoula Bensaida ${ }^{1}$, Mohd Faizul Idham $^{1,2}$, Yuji Sugihara ${ }^{3}$, and \\ Osama Eljamal ${ }^{1 *}$. \\ ${ }^{1}$ Water and Environmental Engineering Laboratory, Department of Earth System Science and Technology, \\ Interdisciplinary Graduate School of Engineering Sciences, Kyushu University, Fukuoka, Japan. \\ ${ }^{2}$ School of Mechanical Engineering, College of Engineering, Universiti Teknologi MARA, Cawangan Terengganu. \\ ${ }^{3}$ Department of Earth System Science and Technology, Interdisciplinary Graduate School of Engineering Sciences, \\ Kyushu University, Fukuoka, Japan. \\ *Corresponding author email: osama-eljamal@kyudai.jp
}

\begin{abstract}
In this study, mini review is presented on the use of different sorbents for radionuclides removal of from water. Four sorbents categories were considered: carbon-based, nanomaterials, bio-sorbents, and miscellaneous sorbents. Carbon-based sorbents showed excellent removal performance towards radionuclides, owing to the high specific surface area and abundant oxygen-containing functional groups. While $F e^{0}$ and $F e^{0}$-based composites was found to exhibit rapid sorption rate, high removal capacity, and strong redox performance for radionuclides, indicating that such nanomaterials can be very promising for in-situ removal of radionuclides, once their drawbacks (aggregation and poor mobility) are overcome. The use of bio-sorbents showed high potential of such materials to remediate radioactive contaminated water under specific environmental conditions. The critical review in this study shall represent a great contribution to the potential researchers and decision makers choosing the highly efficient, feasible, and environmentally friendly sorbents for the removal of radionuclides from aqueous solutions.
\end{abstract}

Keywords: radionuclides; sorption; mini review; nanomaterials; bio-sorbents.

\section{INTRODUCTION}

Water is the source of life on earth, and it is and will be the major challenge for our existence to have a drinkable and uncontaminated water. The main sources of water contamination are, discharging wastewater from industrial activities, municipal wastewater, human agricultural activities, and environmental/global changes [1].

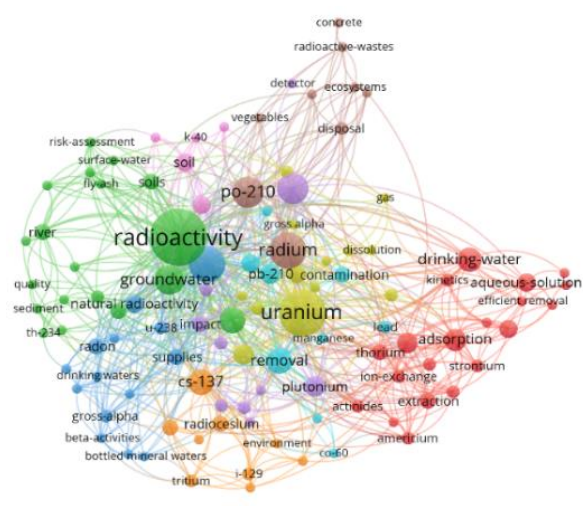

Fig. 1. Bibliometric map of radionuclides-related keywords occurrence in the literature (Scopus database 2011-2021).

Owing to the current grown concern with the development of nuclear power, water contamination with radionuclides has become another great environmental concern. Radionuclides are chemical elements emitting either $\alpha$-, $\beta$-, or $\gamma$-rays, or neutrons, which can be classified as naturally occurring and anthropogenic [2]. The naturally occurring radionuclides include uranium $\left({ }^{238} \mathrm{U}\right.$, and $\left.{ }^{235} \mathrm{U}\right)$, thorium $\left({ }^{232} \mathrm{Th}\right)$, tritium $\left({ }^{3} \mathrm{H}\right)$, etc. While the anthropogenic radionuclides mostly include isotopes of cesium $\left({ }^{137} \mathrm{Cs}\right)$, iodine $\left({ }^{129} \mathrm{I}\right)$, strontium $\left({ }^{90} \mathrm{Sr}\right)$, technetium $\left({ }^{99} \mathrm{Tc}\right)$, plutonium $\left({ }^{239} \mathrm{Pu}\right)$, cobalt $\left({ }^{60} \mathrm{Co}\right)$, radium $\left({ }^{226} \mathrm{Ra}\right.$, and $\left.{ }^{228} \mathrm{Ra}\right)$, radon $\left({ }^{222} \mathrm{Rn}\right)$, and americium $\left({ }^{241} \mathrm{Am}\right)$ [3]. Figure 1 shows the bibliometric map of radionuclides-related keywords occurrence in the literature based on Scopus database within the period from 2011-2021. Such bibliographic map reflected the emerging concern towards most of the formerly mentioned radionuclides and the clear connection with their presence in water, monitoring, and removal technologies.
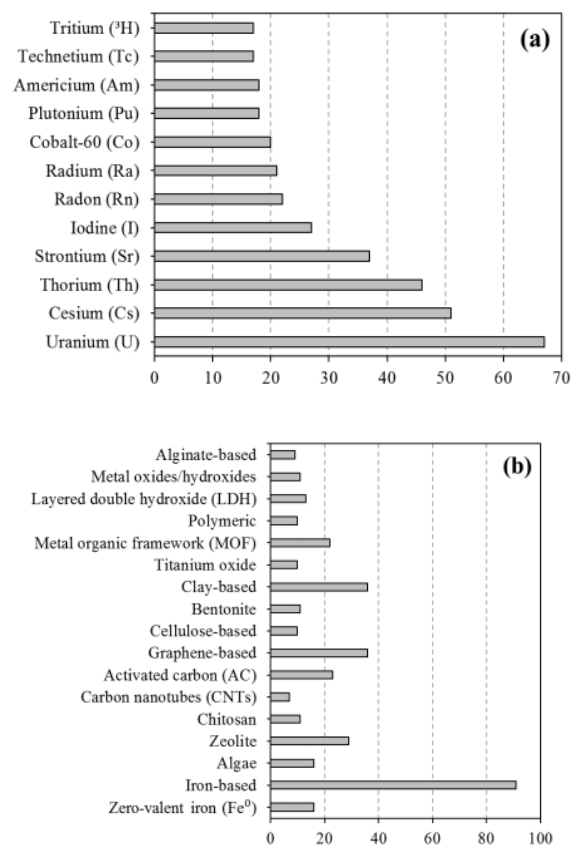

Fig. 2. Number of publications of (a) radionuclides removal from water, and (b) sorbents used for radionuclides removal from water (Scopus database 2011-2021).

The main source of the presence and release of the anthropogenic radionuclides into water bodies is the 
radioactive waste generated by nuclear power plants, nuclear weapon production and/or testing, and nuclear fuel processing units. The exposure to contaminated water with radionuclides may have more detrimental health concerns because of the chemical as well as radiological toxicities, including cancer at different organs (lungs, breast, colon esophagus, thyroid, and ovary), birth defects, neurological disorders, and infertility [4,5]. Owing to such multi-toxic nature in addition to the long half-life time of the radionuclides, the world health organization (WHO), and U.S. environmental protection agency (USEPA) recommended maximum contamination levels of radionuclides in water. Hence, several reported research studies have been concerned with developing different technologies for the removal of radionuclides from aqueous solutions. As presented in Fig. 2(a), and based on Scopus database, around 361 studies were reported in the literature within the last decade on the removal of the most concerning naturally occurring and anthropogenic radionuclides from water. Uranium and cesium topped this list with a total publications number of 67 and 51, respectively. Followed by thorium, strontium, iodine, and then the others. To date, various conventional and modern removal technologies have been considered in the literature for the removal of radionuclides from aqueous solutions, including chemical precipitation, ion exchange, reverse osmosis (RO), electrodialysis, solvent extraction, and evaporation [6-11]. Precipitation is relatively simple and cost effective in converting the aqueous radionuclides into hydroxides, sulfides, and carbonate precipitates. While ion exchange and $\mathrm{RO}$ are the most widely used in the ex-situ removal of radionuclides from contaminated groundwater. All of these approaches have been experimentally and theoretically evaluated for the separation of radionuclides from aqueous solutions. However, most of these methods still present limitations in terms of the high installation costs, secondary pollution, and complex operation. Impressively, sorption technology has recently attracted great attention for its merits as a highly efficient, versatile, and easy-to-operate technique for eliminating trace levels of radionuclides from water [12]. Within the past 10 years, different kinds of sorbents have been extensively investigated for the removal of radionuclides from aqueous solutions, including nanoscale zerovalent iron $\left(\mathrm{Fe}^{0}\right)$, graphene oxide $(\mathrm{GO})$, zeolite, carbon nanotubes (CNTs), activated carbon (AC), etc., as shown in Fig. 2(b). All of these reported sorbents have their pros and cons, in terms of the reactivity, applicability, and feasibility.

Hence, in this study, a mini review is presented on the removal of radionuclides from water via sorption technique considering several reported sorbents in the literature, categorized as 4 major types, including carbonbased sorbents, nanomaterials, bio-sorbents, and miscellaneous sorbents. The main aim of this study is to present a critical review on the performance of such sorbents in radionuclides removal from water to help the potential researchers and decision makers choosing the coming path for research and development towards highly efficient, feasible, and environmentally friendly sorbents for the removal of radionuclides from aqueous solutions.

\section{SORPTION of RADIONUCLIDES}

A wide range of sorbents have been reported in the literature for the removal of radionuclides from aqueous solutions. For the simplicity, sorbents have been classified into 4 different categories, as follows.

\subsection{Carbon-based sorbents}

Several carbonaceous materials have been reported in the literature for the sorption of radionuclides from aqueous solutions, such as activated carbon (AC), graphene oxide (GO), reduced graphene oxide (rGO), and carbon nanotubes (CNTs). These carbon-based materials have great abilities as sorbents owing to their higher acid-base stability than other inorganic sorbents, in addition to the better thermal resistance comparing with organic exchanger resins $[13,14]$. Table 1 summarizes some of the reported studies on radionuclides removal by carbonbased materials.

\subsubsection{Activated carbon (AC)}

$\mathrm{AC}$ is advantaged by its remarkable specific surface area $\left(500-1500 \mathrm{~m}^{2} / \mathrm{g}\right)$ in addition to the microporous structure [15]. Generally, several carbonaceous materials were utilized in the preparation of AC, including agricultural byproducts such as wood, coal, coconut husks, bamboo, plum kernels, lignin, etc. [16-18]. It has been reported before that pure $\mathrm{AC}$ has shown good removal performance towards U(VI), especially at acidic conditions, with maximum sorption capacity of 28.30 $\mathrm{mg} / \mathrm{g}$ [13]. While Chen et al. reported that combining AC with GO in one composite resulted in a higher $\mathrm{U}(\mathrm{VI})$ sorption capacity of $298 \mathrm{mg} / \mathrm{g}$ at less acidic conditions (pH 5.5) [19]. Meanwhile, Moloukhia et al. found that modified AC synthesized from coconut shells was able to remove $\mathrm{Cs}(\mathrm{I})$ and $\mathrm{Sr}(\mathrm{II})$ with saturation capacities of 69.85 and $60.00 \mathrm{mg} / \mathrm{g}$, respectively [20]. The sorption mechanism that mainly governs the removal of radionuclides by $\mathrm{AC}$ is the electrostatic interaction, via repulsion or attraction). Hence, modifying AC's surface with different functional groups (e.g., hydroxyl, carbonyl, carboxyl, methyl, etc.) could be one of the techniques that enhances the sorption capacity towards radionuclides [21]. In such regard, it was reported that maximum ${ }^{60} \mathrm{Co}$ sorption capacity of $121 \mathrm{mg} / \mathrm{g}$ was achieved by AC prepared from doum stone (activated with $\mathrm{H}_{3} \mathrm{PO}_{4}$ ), with the involvement of sorption and ratecontrolling removal mechanisms [22].

\subsubsection{Graphene-based}

Graphene oxide (GO) is one of the suitable materials for radionuclides removal because of the availability of oxygen functional groups on its surface. It has been reported before that the sorption mechanism of U(VI) on GO surface was inner-sphere surface complexation, and the high sorption capacity was achieved owing to the good dispersive features of GO which provided more available sorption sites [23]. While in case of $\mathrm{Cs}(\mathrm{I})$ and $\mathrm{Sr}$ (II) sorption by GO, ion exchange was the main removal mechanism involved [24]. Manipulating the microstructure and self-assembly of GO can enhance its colloidal behavior within radionuclides removal from aqueous solutions. 
Table 1. Radionuclides sorption by carbon-based materials

\begin{tabular}{|c|c|c|c|c|c|c|}
\hline Sorbent & Nuclide & $\begin{array}{l}\begin{array}{l}\text { Initial conc. } \\
(\mathrm{mg} / \mathrm{L})\end{array} \\
\end{array}$ & $\begin{array}{l}\text { Sorbent } \\
\text { dosage }(\mathrm{g} / \mathrm{L})\end{array}$ & $\mathrm{pH}$ & $\begin{array}{l}\text { Maximum sorption } \\
\text { capacity }(\mathrm{mg} / \mathrm{g})\end{array}$ & Ref. \\
\hline \multirow{5}{*}{$\mathrm{AC}$} & $\mathrm{U}(\mathrm{VI})$ & 100 & 1.0 & 3.0 & 28.30 & {$[13]$} \\
\hline & $\mathrm{U}(\mathrm{VI})$ & 200 & 1.2 & 4.5 & 82.00 & [14] \\
\hline & $\mathrm{U}(\mathrm{VI})$ & 50 & 4.0 & 5.0 & 8.20 & [25] \\
\hline & $\begin{array}{l}\mathrm{Cs}(\mathrm{I}) \\
\mathrm{Sr}(\mathrm{II})\end{array}$ & 100 & 5.0 & 6.5 & $\begin{array}{l}67.90 \\
29.60\end{array}$ & [26] \\
\hline & $\mathrm{Co}(\mathrm{II})$ & $100-250$ & 1.2 & 6.0 & 121.0 & {$[22]$} \\
\hline \multirow[t]{2}{*}{ GO } & $\mathrm{U}(\mathrm{VI})$ & - & 0.4 & 4.0 & 299.0 & [27] \\
\hline & $\operatorname{Sr}(I I)$ & 20 & 0.5 & 7.0 & 702.18 & [28] \\
\hline \multirow[t]{2}{*}{ GO-AC } & $\mathrm{U}(\mathrm{VI})$ & 50 & 0.2 & 5.5 & 298.0 & [19] \\
\hline & $\operatorname{Th}(\mathrm{IV})$ & 20 & 0.2 & 4.0 & 32.60 & [ר०] \\
\hline \multirow[t]{2}{*}{ MWCNTs-Fe ${ }_{3} \mathrm{O}_{4}$} & $\mathrm{U}(\mathrm{VI})$ & 20 & 0.2 & 4.0 & 36.3 & [29] \\
\hline & $\operatorname{Sr}(\mathrm{II})$ & 0.018 & 0.6 & 7.0 & - & [30] \\
\hline Ca/Al-LDH-MWCNTs & $\mathrm{U}(\mathrm{VI})$ & 30 & 0.1 & 6.0 & 115.0 & [31] \\
\hline
\end{tabular}

\subsubsection{Carbon nanotubes (CNTs)}

CNTS have unique structural, physico-chemical, mechanical, and electronic properties. They can be classified according to their structure into single-wall carbon nanotubes (SWCNTs), and multi-wall carbon nanotubes (MWCNTs). MWCNTs are much stronger than SWCNTs, related to the involvement of several tubes set in concentric layers within the cylindrical shape. Moreover, MWCNTs can exhibit higher efficiency than SWCNTs, especially in the highly corrosive environment, owing to the low oxygen reduction when used as a catalyst. It has been reported that doping the surface of MWCNTs with other efficient materials can enhance its performance towards radionuclides removal. Magnetic MWCNTs, as a composition with $\mathrm{Fe}_{3} \mathrm{O}_{4}$, showed good sorption performance towards $\mathrm{U}(\mathrm{VI})$, $\mathrm{Th}(\mathrm{IV})$ and $\mathrm{Sr}(\mathrm{II})$, with a clear dependency on $\mathrm{pH}$ and ionic strength $[29,30]$. While decorating MWCNTs with $\mathrm{Ca} / \mathrm{Al}$ layered double hydroxides resulted in enhanced sorption capacity of $\mathrm{U}(\mathrm{VI})$ [31].

\subsection{Nanomaterial sorbents}

\subsubsection{Iron-based}

Iron is the fourth most abundant element on the Earth. The main two aqueous forms of iron are the relatively water soluble $\mathrm{Fe}(\mathrm{II})$ and the highly water insoluble $\mathrm{Fe}$ (III) [32-37]. Zero valent iron $\left(\mathrm{Fe}^{0}\right)$ is one of the iron forms that can be found under specific environmental conditions [38-41]. $\mathrm{Fe}^{0}$ is one of the most widely used reactive nanomaterials in water treatment applications within the last decade. The unique features of $\mathrm{Fe}^{0}$, represented in the nano size, high redox potential, coreshell structure, and high specific surface area, enables it to remove most of the soluble contaminants via several removal mechanisms (e.g., sorption, precipitation, coprecipitation, and reduction) [42-46]. As presented in Table 2, the use of iron-based sorbents in the removal of radionuclides from water has been intensively reported in the literature, owing to the great sorption abilities of such materials [47]. It has been reported before that $\mathrm{Fe}^{0}$ could efficiently remove $\mathrm{Tc}(\mathrm{VII})$ with maximum sorption capacity of $27.5 \mathrm{mg} / \mathrm{g}$ [48]. Doping the surface of $\mathrm{Fe}^{0}$ with $\mathrm{Cu}$ resulted in better anti-aggregation effect and hence enhanced removal of ${ }^{137} \mathrm{Cs}$ [49]. Furthermore, supporting $\mathrm{Fe}^{0}$ on $\mathrm{LDH}$ improved its sorption capacity towards $\mathrm{U}(\mathrm{VI})$ to reach $176 \mathrm{mg} / \mathrm{g}$ at $\mathrm{pH} 5.0$ [50].

\subsubsection{Metal oxides/hydroxides}

Different metal oxides/and hydroxides have been investigated in the literature for radionuclides removal. For instance, titanium oxide $\left(\mathrm{TiO}_{2}\right)$ which has high chemical stability within a wide $\mathrm{pH}$ range in aqueous systems. It has been reported that the presence of HCOONa would enhance the removal effect of U(VI) on the surface of $\mathrm{TiO}_{2}$ with improved sorption effect from $178 \mathrm{mg} / \mathrm{g}$ to $221 \mathrm{mg} / \mathrm{g}$ [51]. While, the 3D $\mathrm{Ag}_{2} \mathrm{O}-$ $\mathrm{Ag} / \mathrm{TiO}_{2}$ composite yielded maximum sorption capacity of radioactive I(I) of $212.77 \mathrm{mg} / \mathrm{g}$ [52]. Furthermore, the use of environmentally-friendly metal hydroxides, such as magnesium hydroxide colloids, have proven their efficiency in the removal of $\mathrm{Am}$ and $\mathrm{Pu}$ from alkaline aqueous solutions towards further applications within nuclear industry processes [53].

\subsection{Natural and bio-sorbents}

\subsubsection{Zeolite}

Zeolites are one of the most effective sorptive materials for the removal of radionuclides from water, due to their high thermal, radiation and mechanical stability, high sorption capacity, and selectivity. Still, they suffer from poor stability due to $\mathrm{Si}$ and $\mathrm{Al}$ dissolution at alkaline $\mathrm{pH}$ range in addition to the separation problems of the spent material [54]. Hence, combining zeolites with another materials, such as $\mathrm{Fe}^{0}$, resulted in better $\mathrm{Cs}(\mathrm{I})$ and $\mathrm{Sr}(\mathrm{II})$ removal and enhanced applicability by the magnetic separation $[55,56]$.

\subsubsection{Bio-sorbents}

Bioremediation of radioactive contaminated water has been intensively studies in the literature, considering different sorbents such as algae-strains and biomass, owing to their biocompatibility and high sorption abilities [57]. Fukuda et al. reported that Galdieria. Sulphuraria cells recovered $52 \pm 15 \%$ of $30 \mu \mathrm{g} / \mathrm{L} \mathrm{Cs}(\mathrm{I})$ within potassium-deficient medium in 10 days [58]. While the accumulation of water-soluble radioiodine was confirmed by the novel strain of microalgae Parachlorella sp. binos (Binos), owing to the thick alginate-containing extracellular matrix and abundant chloroplasts [59]. Such findings give a clear indication of the high potential of using bio-sorbents to remediate radioactive contaminated water under specific 
environmental conditions.

Table 2. Radionuclides sorption by iron-based nanomaterials

\begin{tabular}{|c|c|c|c|c|c|c|}
\hline Sorbent & Nuclide & $\begin{array}{l}\text { Initial conc. } \\
(\mathrm{mg} / \mathrm{L})\end{array}$ & $\begin{array}{l}\text { Sorbent } \\
\text { dosage }(\mathrm{g} / \mathrm{L})\end{array}$ & $\mathrm{pH}$ & $\begin{array}{l}\text { Maximum sorption } \\
\text { capacity }(\mathrm{mg} / \mathrm{g})\end{array}$ & Ref. \\
\hline \multirow[t]{3}{*}{$\mathrm{Fe}^{0}$} & $\mathrm{Tc}(\mathrm{VII})$ & $0.32-32$ & - & 6.8 & 27.5 & [48] \\
\hline & ${ }^{137} \mathrm{Cs}$ & 100 & 20 & 8.0 & 2.60 & [49] \\
\hline & $\mathrm{U}(\mathrm{VI})$ & 10 & 0.1 & 5.0 & 27.0 & [50] \\
\hline $\mathrm{Fe}^{0} / \mathrm{Cu}$ & ${ }^{137} \mathrm{Cs}$ & 100 & 20 & 8.0 & 3.10 & [49] \\
\hline $\mathrm{LDH} @ \mathrm{Fe}^{0}$ & $\mathrm{U}(\mathrm{VI})$ & 10 & 0.1 & 5.0 & 176.0 & [50] \\
\hline $\mathrm{Fe}^{0} /$ biochar & $\mathrm{U}(\mathrm{VI})$ & 20 & 2.0 & 7.0 & 55.14 & [60] \\
\hline $\mathrm{Fe}^{0} /$ carbon nanofiber & $\mathrm{U}(\mathrm{VI})$ & 20 & 0.5 & 3.5 & 39.53 & [61] \\
\hline $\mathrm{Fe}^{0} / \mathrm{CMC}$ & $\mathrm{U}(\mathrm{VI})$ & 60 & 3.0 & 5.0 & 322.5 & [62] \\
\hline $\mathrm{Fe}_{3} \mathrm{O}_{4}$ & $\mathrm{U}(\mathrm{VI})$ & 21.7 & 0.1 & 9.0 & 70.7 & [63] \\
\hline $\mathrm{Fe}_{3} \mathrm{O}_{4} / \mathrm{SiO}_{2}$ & $\mathrm{Eu}(\mathrm{III})$ & $0.0001 \mathrm{M}$ & - & 7.0 & 37.9 & [64] \\
\hline $\mathrm{Fe}_{3} \mathrm{O}_{4} /$ magnesium silicate & $\mathrm{U}(\mathrm{VI})$ & $0.00002 \mathrm{M}$ & 1.0 & 5.5 & 242.5 & [65] \\
\hline Prussian blue/ $\mathrm{Fe}_{3} \mathrm{O}_{4}$ & $\mathrm{Cs}(\mathrm{I})$ & - & - & 5.5 & 16.2 & [66] \\
\hline Magnetic chitosan beads & $\operatorname{Sr}(\mathrm{II})$ & $5-50$ & 1.3 & 8.2 & 11.6 & [67] \\
\hline Fungus/ $\mathrm{Fe}_{3} \mathrm{O}_{4}$ & Th(IV) & 20 & 0.2 & 3.0 & 101 & [68] \\
\hline
\end{tabular}

\subsection{Miscellaneous sorbents}

\subsubsection{Metal organic frameworks (MOFs)}

The inorganic-organic hybrid porous materials, known as metal organic frameworks (MOFs), are unique with their ultrahigh/permanent porosity, flexibility in structure tuning, high surface area, and water stability [69]. Hence, several studies have reported the use of MOFs for radionuclides removal from aqueous solutions via several removal mechanisms, with high sorption capacity values (ranged from 100 to $350 \mathrm{mg} / \mathrm{g}$, up to date), towards U(VI), Cs(I), Sr(II), and Th(IV) [70-73]. The highest sorption capacity was recorded for the sorption of $\mathrm{U}(\mathrm{VI})$ by the amino-functionalized acid resistant MOFs [74].

\subsubsection{Cellulose-based}

Cellulose is the most broadly distributed and regenerative biopolymer in nature, a very promising and low-cost raw material for preparing various functional materials. Cellulose-based materials have been greatly utilized in the immobilization of radioactive wastes from aqueous solutions. Abdel-Galil et al. reported that using cellulose $/ \mathrm{HO}_{7} \mathrm{Sb}_{3}$ nanocomposite for $\mathrm{Cs}(\mathrm{I})$ and $\mathrm{Co}(\mathrm{II})$ removal yielded maximum sorption capacity of around 13.0 and $22.0 \mathrm{mg} / \mathrm{g}$, respectively, owing to the presence of bifunctional ion-exchange groups $(\mathrm{C}-\mathrm{OH}$ and $\mathrm{Sb}-\mathrm{OH})$ [75]. Developing bacterial cellulose membrane modified with EDTA provided a new route for integrating the cellulose-based sorbents in an efficient membrane for the removal of $\mathrm{Sr}(\mathrm{II})$ with maximum sorption capacity of $44.86 \mathrm{mg} / \mathrm{g}$ [76].

\subsubsection{Layered double hydroxides (LDHs)}

LDHs were discovered in the 1840 s as typical anionic layered structure compounds composed of positively charged host layers and guest interlayer anions, which are assembled by the non-covalent bond interaction [77,78] Their environmental potential can be clearly observed redox reactions, and photocatalysis [79]. Generally, LDHs are expressed as the formula $\left[\mathrm{M}^{2+}{ }_{1-\mathrm{x}} \mathrm{M}^{3+}{ }_{\mathrm{x}}(\mathrm{OH})_{2}\right]^{\mathrm{x}+}\left(\mathrm{A}^{\mathrm{m}-}\right)_{\mathrm{x} / \mathrm{m}} \cdot \mathrm{nH}_{2} \mathrm{O}$, where $\mathrm{M}^{2+}$ and $\mathrm{M}^{3+}$ represent the divalent $\left(\mathrm{Mg}^{2+}, \mathrm{Zn}^{2+}, \mathrm{Co}^{2+}, \mathrm{Mn}^{2+}, \mathrm{Ni}^{2+}\right.$, and $\left.\mathrm{Ca}^{2+}\right)$ or trivalent $\left(\mathrm{Al}^{3+}, \mathrm{Fe}^{3+}\right.$, and $\left.\mathrm{Cr}^{3+}\right)$ metal cations,
$\mathrm{A}^{\mathrm{m}-}$ is the interlayer charge-balancing anion (e.g., $\mathrm{Cl}^{-}$, $\mathrm{ClO}_{4}{ }^{-}, \mathrm{NO}_{3}{ }^{-}, \mathrm{CO}_{3}{ }^{2-}$, and $\left.\mathrm{SO}_{4}{ }^{2-}\right)$, and $x$ is regarded as the molar ratio of $\mathrm{M}^{2+} /\left(\mathrm{M}^{2+}+\mathrm{M}^{3+}\right)$ [80].

It has been previously reported that preparing $\mathrm{MgCoAl}-$ LDHs yielded high catalytic activation energy (60.5 kJ/mol) [81]. Using Ca/Al LDH@CNTs composite for efficient removal of ${ }^{241} \mathrm{Am}(\mathrm{III})$ and U(VI) from water was studied by Chen et al. [31]. Moreover, ion exchange was the main removal mechanism in the sorption of $\mathrm{I}^{-}$and $\mathrm{TcO}_{4}{ }^{-}$onto $\mathrm{Mg}$-Al-LDHs [82,83]. While intercalating $\mathrm{Zn}-\mathrm{Al}-\mathrm{LDH}$ with hexacyanoferrate (II) ions resulted in a maximum sorption capacity towards $\mathrm{Cs}(\mathrm{I})$ of $56.2 \mathrm{mg} / \mathrm{g}$ at $\mathrm{pH} 6.0$ [84]. Several LDH-based sorbents; $\mathrm{SiO}_{2} @ \mathrm{LDH}, \mathrm{Fe}_{3} \mathrm{O}_{4} @$ polydopamine@LDH, graphitic- $\mathrm{C}_{3} \mathrm{~N}_{4} @ \mathrm{LDH}$, and polydopamine@LDH, were utilized for U(VI) removal from aqueous solutions, where they showed maximum sorption capacities at $\mathrm{pH}$ 5.0 and $25^{\circ} \mathrm{C}$ (considering different sorbent dosage) of $303.1,344.4,99.7$, and $142.9 \mathrm{mg} / \mathrm{g}$, respectively [85-88].

\subsubsection{Alginate-based}

Alginate is a natural polysaccharide that can be extracted from brown algae. It has several advantageous features to be non-toxic, polymeric structure, biodegradable, biocompatible, and rich with carboxyl and hydroxyl functional groups, which makes it one of the candidates for radionuclides removal from aqueous solutions. Hence, alginate-based sorbents; alginate/humic acid/Feamino clay, Prussian blue impregnated in alginate gel, graphite nano carbon/alginate, and graphene oxide encapsulated polyvinyl alcohol/sodium alginate hydrogel, have shown great removal performance towards several radioactive elements, including $\mathrm{Sr}(\mathrm{II})$, $\mathrm{Cs}(\mathrm{I}), \mathrm{Co}(\mathrm{II})$, and U(VI), with high values of maximum sorption capacity $45.65,55.6,11.63,403.78 \mathrm{mg} / \mathrm{g}$, respectively [89-92].

\section{CONCLUSIONS \& PERSPECTIVES}

The environmental applications of different sorbents have been briefly reviewed in this study for the removal of radionuclides from aqueous solutions. Carbon-based sorbents showed excellent removal performance towards 
radionuclides, owing to the high specific surface area and abundant oxygen-containing functional groups. The defects of GO, represented in high cost and easy aggregation, were solved via considering different inorganic and organic modified carbon-based materials, aiming to design and prepare the more efficient and practical carbon-based sorbents. $\mathrm{Fe}^{0}$ and $\mathrm{Fe}^{0}$-based composites was found to exhibit rapid sorption rate, high removal capacity, and strong redox performance for radionuclides, indicating that such nanomaterials can be very promising for in-situ removal of radionuclides in environmental remediation once their drawbacks (aggregation and poor mobility) are overcome. Utilizing the water-stable MOFs in radionuclides removal from water can yield great sorption performance via several removal mechanisms, including ion exchange, combined sorption-reduction, electrostatic interaction, hydrogen binding, coordination interaction, and Lewis acid-base interaction. Integrating cellulose-based sorbents in a membrane structure can provide high hydrophilicity and easy separation for the sorption of radionuclides in aqueous solutions. The structural properties of LDHs yielded outstanding characteristics in terms of the existence of multiple alternative metal cations allowing chemical compositions of host layers to be precisely controlled, and the unique memory effect resulting in the restorability to their original layered structures. Such unique features enabled LDH-based nanomaterials to show great performance in radionuclides removal from water. The advantages of alginate-based sorbents have been depicted, in terms of the biocompatibility, biodegradability, non-toxicity, polymeric structure, abundancy and strong affinity to aqueous radionuclides. Hence, more attention should be paid on the development of alginate-based sorbents that are multipurpose, ecofriendly and potentially beneficial to wastewater treatment application. In term of cost-effectiveness, more work should be pursued to recycle the adsorbents using effective desorption agent and regeneration strategies.

\section{REFERENCES}

[1] N.B. Singh, G. Nagpal, S. Agrawal, Rachna, Water purification by using Adsorbents: A Review, Environ. Technol. Innov. 11 (2018) 187-240.

[2] D.A. Atwood, Radionuclides in the Environment, John Wiley \& Sons, 2013.

[3] S.M. Husnain, W. Um, Y.-S. Chang, Magnetitebased adsorbents for sequestration of radionuclides: a review, RSC Adv. 8 (2018) 2521-2540.

[4] G.R. Najem, L.K. Voyce, Health effects of a thorium waste disposal site., Am. J. Public Health. 80 (1990) 478-480.

[5] M.K. L, Restructuring nuclear regulations., Environ. Health Perspect. 111 (2003) 13-17.

[6] S. Kulkarni, A. Ballal, S.K. Apte, Bioprecipitation of uranium from alkaline waste solutions using recombinant Deinococcus radiodurans, J. Hazard. Mater. 262 (2013) 853861 .

[7] I.A. Katsoyiannis, A.I. Zouboulis, Removal of uranium from contaminated drinking water: a mini review of available treatment methods, Desalin. Water Treat. 51 (2013) 2915-2925.
[8] B.J. Lesikar, R. Melton, M. Hare, J. Hopkins, M. Dozier, Drinking Water Problems: Radionuclides (Spanish), Texas FARMER Collect. (2006).

[9] A. AC03295178, Handling and processing of radioactive waste from nuclear applications, Internat. Atomic Energy Agency, 2001.

[10] A.C.Q. Ladeira, C.A. de Morais, Uranium recovery from industrial effluent by ion exchange - column experiments, Miner. Eng. 18 (2005) 1337-1340.

[11] C.F. Baes Jr, R.A. Zingaro, C.F. Coleman, The extraction of uranium (VI) from acid perchlorate solutions by Di-(2-ethyl-hexyl)-phosphoric acid in n-hexane, J. Phys. Chem. 62 (1958) 129-136.

[12] X. Li, Y. Liu, C. Zhang, T. Wen, L. Zhuang, X. Wang, G. Song, D. Chen, Y. Ai, T. Hayat, Porous $\mathrm{Fe} 2 \mathrm{O} 3$ microcubes derived from metal organic frameworks for efficient elimination of organic pollutants and heavy metal ions, Chem. Eng. J. 336 (2018) 241-252.

[13] A. Mellah, S. Chegrouche, M. Barkat, The removal of uranium(VI) from aqueous solutions onto activated carbon: Kinetic and thermodynamic investigations, J. Colloid Interface Sci. 296 (2006) 434-441.

[14] Y. Zhao, C. Liu, M. Feng, Z. Chen, S. Li, G. Tian, L. Wang, J. Huang, S. Li, Solid phase extraction of uranium(VI) onto benzoylthiourea-anchored activated carbon, J. Hazard. Mater. 176 (2010) 119-124.

[15] P. Chingombe, B. Saha, R.J. Wakeman, Surface modification and characterisation of a coal-based activated carbon, Carbon N. Y. 43 (2005) 31323143.

[16] T. Karanfil, J.E. Kilduff, Role of granular activated carbon surface chemistry on the adsorption of organic compounds. 1. Priority pollutants, Environ. Sci. Technol. 33 (1999) 3217-3224.

[17] F.-C. Wu, R.-L. Tseng, R.-S. Juang, Pore structure and adsorption performance of the activated carbons prepared from plum kernels, J. Hazard. Mater. 69 (1999) 287-302.

[18] B.H. Hameed, A.T.M. Din, A.L. Ahmad, Adsorption of methylene blue onto bamboobased activated carbon: Kinetics and equilibrium studies, J. Hazard. Mater. 141 (2007) 819-825.

[19] S. Chen, J. Hong, H. Yang, J. Yang, Adsorption of uranium (VI) from aqueous solution using a novel graphene oxide-activated carbon felt composite, J. Environ. Radioact. 126 (2013) 253-258.

[20] H. Moloukhia, W.S. Hegazy, E.A. Abdel-Galil, S.S. Mahrous, Removal of $\mathrm{Eu} 3+, \mathrm{Ce} 3+, \mathrm{Sr} 2+$, and $\mathrm{Cs}+$ ions from radioactive waste solutions by modified activated carbon prepared from coconut shells, Chem. Ecol. 32 (2016) 324-345.

[21] G.I.L. PARK, H.S.O.O. PARK, S.I.H.L. WOO, Influence of $\mathrm{pH}$ on the adsorption of uranium ions by oxidized activated carbon and chitosan, Sep. Sci. Technol. 34 (1999) 833-854.

[22] M.M. Hamed, M.M.S. Ali, M. Holiel, Preparation of activated carbon from doum stone and its application on adsorption of $60 \mathrm{Co}$ and 
152+154Eu: Equilibrium, kinetic and thermodynamic studies, J. Environ. Radioact. 164 (2016) 113-124.

[23] Y. Sun, S. Yang, Y. Chen, C. Ding, W. Cheng, $\mathrm{X}$. Wang, Adsorption and Desorption of U(VI) on Functionalized Graphene Oxides: A Combined Experimental and Theoretical Study, Environ. Sci. Technol. 49 (2015) 4255-4262.

[24] A.Y. Romanchuk, A.S. Kuzenkova, A.S. Slesarev, J.M. Tour, S.N. Kalmykov, Cs(I) and Sr(II) Sorption onto Graphene Oxide, Solvent Extr. Ion Exch. 34 (2016) 594-602.

[25] C. Kütahyal1, M. Eral, Selective adsorption of uranium from aqueous solutions using activated carbon prepared from charcoal by chemical activation, Sep. Purif. Technol. 40 (2004) 109114.

[26] M. Ali, N.M. Sami, A.A. El-Sayed, Removal of $\mathrm{Cs}+, \mathrm{Sr} 2+$ and $\mathrm{Co} 2+$ by activated charcoal modified with Prussian blue nanoparticle (PBNP) from aqueous media: kinetics and equilibrium studies., J. Radioanal. Nucl. Chem. 324 (2020).

[27] Z. Li, F. Chen, L. Yuan, Y. Liu, Y. Zhao, Z. Chai, W. Shi, Uranium (VI) adsorption on graphene oxide nanosheets from aqueous solutions, Chem. Eng. J. 210 (2012) 539-546.

[28] T. Wen, X. Wu, M. Liu, Z. Xing, X. Wang, A.W. Xu, Efficient capture of strontium from aqueous solutions using graphene oxidehydroxyapatite nanocomposites, Dalt. Trans. 43 (2014) 7464-7472.

[29] E. Zolfonoun, S.R. Yousefi, Sorption and preconcentration of uranium and thorium from aqueous solutions using multi-walled carbon nanotubes decorated with magnetic nanoparticles, Radiochim. Acta. 103 (2015) 835-841.

[30] C. Chen, J. Hu, D. Shao, J. Li, X. Wang, Adsorption behavior of multiwall carbon nanotube/iron oxide magnetic composites for $\mathrm{Ni}(\mathrm{II})$ and $\mathrm{Sr}(\mathrm{II})$, J. Hazard. Mater. 164 (2009) 923-928.

[31] H. Chen, Z. Chen, G. Zhao, Z. Zhang, C. Xu, Y. Liu, J. Chen, L. Zhuang, T. Haya, X. Wang, Enhanced adsorption of U(VI) and 241Am(III) from wastewater using $\mathrm{Ca} / \mathrm{Al}$ layered double hydroxide@carbon nanotube composites, J. Hazard. Mater. 347 (2018) 67-77.

[32] R. Eljamal, O. Eljamal, I. Maamoun, G. Yilmaz, Y. Sugihara, Enhancing the characteristics and reactivity of nZVI: Polymers effect and mechanisms, J. Mol. Liq. 315 (2020) 113714.

[33] I. Maamoun, O. Eljamal, R. Eljamal, O. Falyouna, Y. Sugihara, Promoting Aqueous and Transport Characteristics of Highly Reactive Nanoscale Zero Valent Iron via Different Layered Hydroxide Coatings, Appl. Surf. Sci. 506 (2020) 145018.

[34] R. Eljamal, I. Kahraman, O. Eljamal, I.P. Thompson, I. Maamoun, G. Yilmaz, Impact of nZVI on the formation of aerobic granules, bacterial growth and nutrient removal using aerobic sequencing batch reactor, Environ. Technol. Innov. 19 (2020) 100911.

[35] T.W.M. Amen, O. Eljamal, A.M.E. Khalil, Y.
Sugihara, N. Matsunaga, Methane yield enhancement by the addition of new novel of iron and copper-iron bimetallic nanoparticles, Chem. Eng. Process. Intensif. 130 (2018) 253-261.

[36] R. Mokete, O. Eljamal, Y. Sugihara, Exploration of the reactivity of nanoscale zero-valent iron (NZVI) associated nanoparticles in diverse experimental conditions, Chem. Eng. Process. Process Intensif. 150 (2020) 107879.

[37] I. Maamoun, O. Eljamal, O. Falyouna, R. Eljamal, Y. Sugihara, Multi-objective optimization of permeable reactive barrier design for $\mathrm{Cr}(\mathrm{VI})$ removal from groundwater, Ecotoxicol. Environ. Saf. 200 (2020) 110773.

[38] I. Maamoun, O. Eljamal, O. Falyouna, R. Eljamal, Y. Sugihara, Stimulating effect of magnesium hydroxide on aqueous characteristics of iron nanocomposites, Water Sci. Technol. 80 (2019) 1996-2002.

[39] S. TAKAMI, O. ELJAMAL, A.M.E. KHALIL, R. ELJAMAL, N. MATSUNAGA, DEVELOPMENT OF CONTINUOUS SYSTEM BASED ON NANOSCALE ZERO VALENT IRON PARTICLES FOR PHOSPHORUS REMOVAL, J. JSCE. 7 (2019) 30-42.

[40] I. Maamoun, R. Eljamal, O. Falyouna, K. Bensaida, Y. Sugihara, O. Eljamal, Insights into kinetics, isotherms and thermodynamics of phosphorus sorption onto nanoscale zero-valent Iron, J. Mol. Liq. (2021) 115402.

[41] I. Maamoun, O. Eljamal, T. Shubair, H. Noutsuka, B.B. Saha, N. Matsunaga, Integrating nano-scale zero valent iron (nZVI) in phosphorus removal from aqueous solution through porous media: packed-column experiment, Proc. Int. Exch. Innov. Conf. Eng. Sci. 3 (2017) 25-30.

[42] I. Maamoun, O. Eljamal, N. Matsunaga, Enhancement of Nanoscale Zero-Valent Iron Stability in Aqueous Solution Via Metal Hydroxide Coating, Proc. Int. Exch. Innov. Conf. Eng. Sci. 4 (2018) 82-83.

[43] I. Maamoun, O. Eljamal, I. Thompson, R. Eljamal, O. Falyouna, Y. Sugihara, Effect of Nano Zero Valent Iron Delivery Method into Porous Media on Phosphorus Removal from Groundwater, Proc. Int. Exch. Innov. Conf. Eng. Sci. 5 (2019) 9-11.

[44] I. Maamoun, O. Falyouna, R. Eljamal, K. Bensaida, O. Eljamal, Optimization modeling of $\mathrm{nFe}$ /Cu-PRB design for $\mathrm{Cr}$ (VI) removal from groundwater, Int J Env. Sci Dev. 12 (2021) 131138.

[45] O. Falyouna, K. Bensaida, I. Maamoun, Y. Sugihara, O. Eljamal, Removal of Ciprofloxacin from Aqueous Solutions by Nanoscale Zerovalent Iron-Based Materials: A Mini Review, Proceeding Int. Exch. Innov. Conf. Eng. Sci. 6 (2020) 179-185.

[46] K. Bensaida, I. Maamoun, R. Eljamal, O. Falyouna, Y. Sugihara, O. Eljamal, Enhancement of Power Generation in Microbial Fuel Cells ( Mfcs ) Using Iron / Copper Nanoparticles, 6th IEICES-2020, Kyushu Univ. Fukuoka, Japan. (2020) 156-162. 
[47] O. Falyouna, O. Eljamal, I. Maamoun, Removal of Cesium from Contaminated Waters by Employing Iron-Based Nanoparticles and Nanocomposites, in: Proceeding Int. Exch. Innov. Conf. Eng. Sci., 2019: pp. 26-27.

[48] D. Li, J.C. Seaman, S.E. Hunyadi Murph, D.I. Kaplan, K. Taylor-Pashow, R. Feng, H. Chang, $\mathrm{M}$. Tandukar, Porous iron material for $\mathrm{TcO} 4-$ and ReO4- sequestration from groundwater under ambient oxic conditions, J. Hazard. Mater. 374 (2019) 177-185.

[49] T. Shubair, O. Eljamal, M.E. AhmedKhalil, A. Tahara, N. Matsunaga, Novel application of nanoscale zero valent iron and bimetallic nano$\mathrm{Fe} / \mathrm{Cu}$ particles for the treatment of cesium contaminated water, J. Environ. Chem. Eng. (2018).

[50] S. Yu, X. Wang, Y. Liu, Z. Chen, Y. Wu, Y. Liu, H. Pang, G. Song, J. Chen, X. Wang, Efficient removal of uranium(VI) by layered double hydroxides supported nanoscale zero-valent iron: A combined experimental and spectroscopic studies, Chem. Eng. J. 365 (2019) 51-59. doi:https://doi.org/10.1016/j.cej.2019.02.024.

[51] J. Wang, D. Kang, X. Yu, M. Ge, Y. Chen, Synthesis and characterization of $\mathrm{Mg}-\mathrm{Fe}-\mathrm{La}$ trimetal composite as an adsorbent for fluoride removal, Chem. Eng. J. 264 (2015) 506-513.

[52] S. Liu, N. Wang, Y. Zhang, Y. Li, Z. Han, P. Na, Efficient removal of radioactive iodide ions from water by three-dimensional $\mathrm{Ag} 2 \mathrm{O}-\mathrm{Ag} / \mathrm{TiO} 2$ composites under visible light irradiation, J. Hazard. Mater. 284 (2015) 171-181.

[53] Z. Maher, P. Ivanov, L. O'Brien, H. Sims, R.J. Taylor, S.L. Heath, F.R. Livens, D. Goddard, S. Kellet, P. Rand, N.D. Bryan, Americium and plutonium association with magnesium hydroxide colloids in alkaline nuclear industry process environments, J. Nucl. Mater. 468 (2016) 84-96.

[54] S. Yamamoto, S. Sugiyama, O. Matsuoka, K. Kohmura, T. Honda, Y. Banno, H. Nozoye, Dissolution of zeolite in acidic and alkaline aqueous solutions as revealed by AFM imaging, J. Phys. Chem. 100 (1996) 18474-18482.

[55] O. Falyouna, O. Eljamal, I. Maamoun, A. Tahara, Y. Sugihara, Magnetic zeolite synthesis for efficient removal of cesium in a lab-scale continuous treatment system, J. Colloid Interface Sci. 571 (2020) 66-79.

[56] T. Shubair, O. Eljamal, A. Tahara, Y. Sugihara, N. Matsunaga, Preparation of new magnetic zeolite nanocomposites for removal of strontium from polluted waters, J. Mol. Liq. 288 (2019) 111026.

[57] I. Maamoun, K. Bensaida, R. Eljamal, O. Falyouna, Y. Sugihara, O. Eljamal, Innovative Biotechnological Applications of Galdieria Sulphuraria-Red Microalgae (GS-RMA) in Water Treatment Systems, Proc. Int. Exch. Innov. Conf. Eng. Sci. 6 (2020) 163-170.

[58] S. Fukuda, R. Yamamoto, K. Iwamoto, A. Minoda, Cellular accumulation of cesium in the unicellular red alga Galdieria sulphuraria under mixotrophic conditions, J. Appl. Phycol. 30
(2018) 3057-3061

[59] H. Shimura, K. Itoh, A. Sugiyama, S. Ichijo, M. Ichijo, F. Furuya, Y. Nakamura, K. Kitahara, K. Kobayashi, Y. Yukawa, Absorption of radionuclides from the Fukushima nuclear accident by a novel algal strain, PLoS One. 7 (2012) e44200.

[60] H. Zhang, Y. Ruan, A. Liang, K. Shih, Z. Diao, M. Su, L. Hou, D. Chen, H. Lu, L. Kong, Carbothermal reduction for preparing $\mathrm{nZVI} / \mathrm{BC}$ to extract uranium: Insight into the iron species dependent uranium adsorption behavior, J. Clean. Prod. 239 (2019) 117873.

[61] B. Hu, X. Mei, X. Li, J. Hu, D. Xu, J. Ma, Y. Huang, Decontamination of U(VI) from nZVI/CNF composites investigated by batch, spectroscopic and modeling techniques, J. Mol. Liq. 237 (2017) 1-9.

[62] I.-C. Popescu (Hoștuc), P. Filip, D. Humelnicu, I. Humelnicu, T.B. Scott, R.A. Crane, Removal of uranium (VI) from aqueous systems by nanoscale zero-valent iron particles suspended in carboxy-methyl cellulose, J. Nucl. Mater. 443 (2013) 250-255.

[63] X.T. Chen, L.F. He, R.Z. Liu, C. Zhang, B. Liu, Y.P. Tang, Effective uranium(vi) sorption from alkaline media using bi-functionalized silicacoated magnetic nanoparticles, RSC Adv. 5 (2015) 56658-56665.

[64] R.S. Carvalho, A.L. Daniel-da-Silva, T. Trindade, Uptake of Europium(III) from Water using Magnetite Nanoparticles, Part. Part. Syst. Charact. 33 (2016) 150-157.

[65] M. Zeng, Y. Huang, S. Zhang, S. Qin, J. Li, J. Xu, Removal of uranium(vi) from aqueous solution by magnetic yolk-shell iron oxide@magnesium silicate microspheres, RSC Adv. 4 (2014) 50215029.

[66] T. Sasaki, S. Tanaka, Magnetic Separation of Cesium Ion Using Prussian Blue Modified Magnetite, Chem. Lett. 41 (2011) 32-34.

[67] Y.-W. Chen, J.-L. Wang, Removal of cesium from radioactive wastewater using magnetic chitosan beads cross-linked with glutaraldehyde, Nucl. Sci. Tech. 27 (2016) 43.

[68] C. Ding, W. Cheng, Y. Sun, X. Wang, Novel fungus-Fe3O4 bio-nanocomposites as high performance adsorbents for the removal of radionuclides, J. Hazard. Mater. 295 (2015) 127 137.

[69] M. Feng, P. Zhang, H.-C. Zhou, V.K. Sharma, Water-stable metal-organic frameworks for aqueous removal of heavy metals and radionuclides: A review, Chemosphere. 209 (2018) 783-800.

[70] J.Q. Li, X.F. Feng, L. Zhang, H.Q. Wu, C.S. Yan, Y.Y. Xiong, H.Y. Gao, F. Luo, Direct extraction of U (VI) from alkaline solution and seawater via anion exchange by metal-organic framework, Chem. Eng. J. 316 (2017) 154-159.

[71] L. Li, W. Ma, S. Shen, H. Huang, Y. Bai, H. Liu, A combined experimental and theoretical study on the extraction of uranium by amino-derived metal-organic frameworks through postsynthetic strategy, ACS Appl. Mater. Interfaces. 
8 (2016) 31032-31041.

[72] B. Aguila, D. Banerjee, Z. Nie, Y. Shin, S. Ma, P.K. Thallapally, Selective removal of cesium and strontium using porous frameworks from high level nuclear waste, Chem. Commun. 52 (2016) 5940-5942.

[73] N. Zhang, L.-Y. Yuan, W.-L. Guo, S.-Z. Luo, Z.F. Chai, W.-Q. Shi, Extending the use of highly porous and functionalized MOFs to Th (IV) capture, ACS Appl. Mater. Interfaces. 9 (2017) 25216-25224.

[74] Z.-Q. Bai, L.-Y. Yuan, L. Zhu, Z.-R. Liu, S.-Q. Chu, L.-R. Zheng, J. Zhang, Z.-F. Chai, W.-Q. Shi, Introduction of amino groups into acidresistant MOFs for enhanced U (VI) sorption, J. Mater. Chem. A. 3 (2015) 525-534.

[75] E.A. Abdel-Galil, H. Moloukhia, M. AbdelKhalik, S.S. Mahrous, Synthesis and physicochemical characterization of cellulose/HO7Sb3 nanocomposite as adsorbent for the removal of some radionuclides from aqueous solutions, Appl. Radiat. Isot. 140 (2018) 363-373.

[76] R. Cheng, M. Kang, S. Zhuang, L. Shi, X. Zheng, J. Wang, Adsorption of Sr(II) from water by mercerized bacterial cellulose membrane modified with EDTA, J. Hazard. Mater. 364 (2019) 645-653.

[77] J. Wang, X. Wang, L. Tan, Y. Chen, T. Hayat, J. Hu, A. Alsaedi, B. Ahmad, W. Guo, X. Wang, Performances and mechanisms of $\mathrm{Mg} / \mathrm{Al}$ and $\mathrm{Ca} / \mathrm{Al}$ layered double hydroxides for graphene oxide removal from aqueous solution, Chem. Eng. J. 297 (2016) 106-115.

[78] S. Alkhudhayri, O. Eljamal, I. Maamoun, R. Eljamal, Thermodynamic Effect on Boron Removal from Aqueous Solutions by $\mathrm{MgAl}$ Layered Double Hydrotalcite, in: Proceeding Int. Exch. Innov. Conf. Eng. Sci. 5, 2019: pp. 19-21.

[79] M.-Q. Zhao, Q. Zhang, W. Zhang, J.-Q. Huang, Y. Zhang, D.S. Su, F. Wei, Embedded high density metal nanoparticles with extraordinary thermal stability derived from guest- host mediated layered double hydroxides, J. Am. Chem. Soc. 132 (2010) 14739-14741.

[80] K. Zhu, Y. Gao, X. Tan, C. Chen, Polyanilinemodified $\mathrm{Mg} / \mathrm{Al}$ layered double hydroxide composites and their application in efficient removal of $\mathrm{Cr}(\mathrm{VI})$, ACS Sustain. Chem. Eng. 4 (2016) 4361-4369.

[81] E. Li, Z.P. Xu, V. Rudolph, MgCoAl-LDH derived heterogeneous catalysts for the ethanol transesterification of canola oil to biodiesel, Appl. Catal. B Environ. 88 (2009) 42-49.

[82] M.J. Kang, K.S. Chun, S.W. Rhee, Y. Do, Comparison of Sorption Behavior of I-and TcO4 on $\mathrm{Mg} / \mathrm{Al}$ Layered Double Hydroxide, Radiochim. Acta. 85 (1999) 57-64.

[83] M.J. Kang, S.W. Rhee, H. Moon, Sorption of MO4-(M= Tc, Re) on $\mathrm{Mg} / \mathrm{Al}$ layered double hydroxide by anion exchange, Radiochim. Acta. 75 (1996) 169-174.

[84] G.N. Pshinko, L.N. Puzyrnaya, S.A. Kobets, V.M. Fedorova, A.A. Kosorukov, V.Y. Demchenko, Layered double hydroxide of $\mathrm{Zn}$ and $\mathrm{Al}$, intercalated with hexacyanoferrate (II) ions, as a sorbent for removing cesium radionuclides from aqueous solutions, Radiochemistry. 57 (2015) 259-265.

[85] D. Yang, S. Song, Y. Zou, X. Wang, S. Yu, T. Wen, H. Wang, T. Hayat, A. Alsaedi, X. Wang, Rational design and synthesis of monodispersed hierarchical SiO2@ layered double hydroxide nanocomposites for efficient removal of pollutants from aqueous solution, Chem. Eng. J. 323 (2017) 143-152.

[86] D. Yang, X. Wang, N. Wang, G. Zhao, G. Song, D. Chen, Y. Liang, T. Wen, H. Wang, T. Hayat, In-situ growth of hierarchical layered double hydroxide on polydopamine-encapsulated hollow $\mathrm{Fe} 3 \mathrm{O} 4$ microspheres for efficient removal and recovery of U (VI), J. Clean. Prod. 172 (2018) 2033-2044.

[87] Y. Zou, P. Wang, W. Yao, X. Wang, Y. Liu, D. Yang, L. Wang, J. Hou, A. Alsaedi, T. Hayat, Synergistic immobilization of UO22+ by novel graphitic carbon nitride@ layered double hydroxide nanocomposites from wastewater, Chem. Eng. J. 330 (2017) 573-584.

[88] K. Zhu, S. Lu, Y. Gao, R. Zhang, X. Tan, C. Chen, Fabrication of hierarchical core-shell polydopamine@MgAl-LDHs composites for the efficient enrichment of radionuclides, Appl. Surf. Sci. 396 (2017) 1726-1735.

[89] Y. Mihara, M.T. Sikder, H. Yamagishi, T. Sasaki, M. Kurasaki, S. Itoh, S. Tanaka, Adsorption kinetic model of alginate gel beads synthesized micro particle-prussian blue to remove cesium ions from water, J. Water Process Eng. 10 (2016) 9-19.

[90] W. Jung, B.-H. Jeon, D.-W. Cho, H.-S. Roh, Y. Cho, S.-J. Kim, D.S. Lee, Sorptive removal of heavy metals with nano-sized carbon immobilized alginate beads, J. Ind. Eng. Chem. 26 (2015) 364-369.

[91] X. Yi, F. Sun, Z. Han, F. Han, J. He, M. Ou, J. $\mathrm{Gu}, \mathrm{X} . \mathrm{Xu}$, Graphene oxide encapsulated polyvinyl alcohol/sodium alginate hydrogel microspheres for $\mathrm{Cu}$ (II) and $\mathrm{U}$ (VI) removal, Ecotoxicol. Environ. Saf. 158 (2018) 309-318.

[92] S.R. Choe, Y. Haldorai, S.-C. Jang, M. Rethinasabapathy, Y.-C. Lee, Y.-K. Han, Y.-S. Jun, C. Roh, Y.S. Huh, Fabrication of alginate/humic acid/Fe-aminoclay hydrogel composed of a grafted-network for the efficient removal of strontium ions from aqueous solution, Environ. Technol. Innov. 9 (2018) 285-293. 